\title{
The Real Exchange Rate-Foreign Direct Investment Controversy in South Africa: An Application of ARDL Approach
}

\author{
Ahmed Mohamed Dahir ${ }^{1}$, Fuaziah Mahat ${ }^{1}$, A. N. Bany-Ariffin ${ }^{1} \&$ Nazrul Hisyam Ab Razak ${ }^{1}$ \\ ${ }^{1}$ Department of Accounting and Finance, Faculty of Economics and Management, University Putra Malaysia, \\ Malaysia \\ Correspondence: Ahmed Mohamed Dahir, Department of Accounting and Finance, Faculty of Economics and \\ Management, University Putra Malaysia, Malaysia. E-mail: ahmedtall20@gmail.com
}

Received: August 17, 2017

Accepted: October 23, 2017

Online Published: October 25, 2017

doi:10.5539/ijef.v9n11p207

URL: https://doi.org/10.5539/ijef.v9n11p207

\begin{abstract}
This paper examines the relationship between real exchange rate and foreign direct investment. We apply autoregressive distributed lag (ARDL) bounds testing method to estimate short and long-run relationships between the series in South Africa over the period of 1987-2016. The results reveal long-run cointegration relationships among variables are confirmed, implying real exchange rate, domestic market size stimulate the foreign direct investment in the long run. Furthermore, there is significant Granger unidirectional causality foreign direct investment to real exchange rate in short and long run and from market size to trade openness in a short run. This finding further suggests that the exchange rate instability are likely to be substantially harmful to a positive effect of FDI and should be avoided in South Africa.
\end{abstract}

Keywords: foreign direct investment, ARDL model, error correction model

\section{Introduction}

The relationship between exchange rate and foreign direct investment is paramount significant in overall macroeconomic factors of any country. Developed and sound financial markets stimulate to attract foreign direct investment (Shahbaz, 2013). The relationship between exchange rates and foreign direct investment has sparked active discussion among academicians, practitioners, and policymakers. That implies that well managed real exchange rates can be crucial to attracting foreign direct investment which improves economic growth in the long run. However, the importance of a relationship between real exchange rate and direct foreign investment is overlooked. Regardless of growing literature on this topic, the existing literature focused on the relationships: exchange rate-led foreign direct investment or foreign direct investment-led exchange rate. But little is known the relationship between real exchange rate and foreign direct investment.

More specifically, developing economies strive to attract investments from foreigners aiming to become industrialized countries. Since resources can be mobilized either domestically or externally, but the domestic funds cannot fulfill the investments required to build industries due to individual savings (Kumar, 2013). Thus, foreign direct investment is needed to spend the import of fixed assets and fill any discrepancies (Iqbal Chaudhry, Mehmood, \& Saqib Mehmood, 2013). Because it has more impact than foreign portfolio investment as it improves the economic growth of a host country, however, it may pose risks to a recipient's economy (Bhasin \& Gupta, 2017a). On the other hand, the direct foreign investment may result in exchange rate fluctuations, such as appreciation or depreciation which may hurt the competitiveness of local products. Whereas a monetary policy like expansionary or contractionary fiscal decisions that aim to specific interest rate also influences real exchange rates (Wong, 2017), consequently, it affects inflows of the foreign direct investment. To that effect, it may cause a negative impact on economic growth.

Notwithstanding the potential risks of FDI as mentioned before, the foreign direct investment thus plays a critical role in the provision of external financing and transporting technology and knowledge such as skills, know-how, advanced technology and research and development (R\&D) to the host economy. These resources are a prerequisite to achieving a targeted economy growth by a country (Iqbal Chaudhry et al., 2013). For example, it transfers a substantial amount of capitals from developed to developing countries. This international capital flow enables them accessibility of new markets, builds infrastructures, creates new employment opportunities thus improving the competitiveness of the domestic economy (Bhasin \& Gupta, 2017a; Kumar, 2013). In other words, 
the foreign direct investment is expected to increase export, production, improve living standards, and reduce inflation. But the effectiveness of FDI is supported by human capacity, financial facilities and level of economy of host countries.

The primary objective of our study is to investigate the effect of real exchange rate on foreign direct investment. This study has several contributions.1) it advances the existing literature by revisiting exchange rate and foreign direct investment in South Africa. 2) we apply econometric estimation: a) testing stationarity of the variables to avoid the spurious results. b) we use cointegration techniques to capture the short and long-run relationship between real exchange rate and foreign direct investment. c) Granger causality is applied to test short, and long run unidirectional/ bidirectional causality between variables, especially variables confirmed cointegration. Therefore, this study concentrates the impacts of real exchange rate, market size, and trade openness on inflows of foreign direct investment. This research is beneficial for both developing and developed economies in which developing countries need to attract foreign direct investment because of their limited capital resources, while developed countries, in turn, need to understand to where to invest as they have excess capitals.

The remainder of this paper is outlined as follows: literature is reviewed in Section 2. Section 3 displays methodology and data descriptions. Section 4 presents the empirical results and discussions. Section 5 contains the conclusion and research implications.

\section{Literature Review}

Many empirical studies on the relationship between real exchange rate and foreign direct investment have mixed results. Notably, the existing literature has focused determinants of FDI which have grown substantially for the last thirty years (Iamsiraroj, 2016). Although the literature covers a wide variety of this field, there is growing importance that gives ample space to research in effects of real exchange rate on foreign direct investment having the advantage to speed up economic growth of developing countries (Tang \& Chua, 2012; Tang, Yip, \& Ozturk, 2014). Similarly, it advances financial markets, sustains stability and impacts positively productivity of the host nations. Thus, to examine the determinants of inward FDI are of the essence for policymakers giving proper attention to estimate factors that have effects on the determinants of inward FDI for developing countries. Because of developing nations, for instance, South Africa aims to attract inwards of FDI that accordingly improves economic growth in the long term (Iamsiraroj, 2016).

Numerous theories have been proposed to elucidate factors which boost foreign direct investment, such as real exchange rate, market size, trade openness, etc. Specifically, theories like Eclectic Paradigm developed by Dunning (1991) that blends industrial organization theory, internalization theory and location theory is adopted in this study. This theory justifies explicitly the rationales in which multinational companies pursue FDI, seeking to benefit lucrative opportunities existing in foreign countries. The profits earned offset losses from unfavorable market situations in home countries and enable them to compete with their industries (Cuyvers, Soeng, Plasmans, \& Van Den Bulcke, 2011; Dunning \& Lundan, 2008).

Apart from the real exchange rate, domestic market size affects the foreign direct investment positively (Cuyvers et al., 2011; Liu, Wang, \& Wei, 2001). However, the sign changes when the cost of transportation of goods or services to foreign markets exceeds the average cost of production within the markets, so that the market size is hypothesized having a negative impact on FDI inflows of receipt countries and it may strain the direct foreign effect. Market size is defined in this study as the attractiveness of market with proxy by the GDP per capital, which means markets in host country whose consumers are wealthy magnetize the FDI. The trade openness influences the direct foreign investment in their positive or negative direction (Cuyvers et al., 2011; Gupta \& Singh, 2016; Iamsiraroj, 2016; Liu et al., 2001; Seetanah \& Rojid, 2011; Severiano, 2011). The country's openness to export, for example, attracts the export-oriented foreign direct investment, while an increase in tariffs and other barriers imposed on exporting trades by host country discourages inflows of FDI.

\section{Econometric Methodology}

\subsection{Model Specification}

The primary objective of this study is to examine the real exchange rate on foreign direct investment in South Africa. We followed Bhasin and Gupta (2017b), and Cuyvers et al. (2011) who underlined that foreign direct investment is strongly influenced by trade openness, market size, and real exchange rates. We collected annual data from the World Development Indicators database on foreign direct investment inflows, trade openness, market size and real exchange rates with 30 observation covering the period of 1987-2016. The FDI inflows are measured by foreign direct investment inflows over GDP ( $\%$ of GDP). Market size is proxied by market capitalization of listed domestic companies over GDP (\% of GDP). Trade openness measured by the sum of 
export and import over GDP (\% of GDP), and real exchange rate which is measured by local currency against a weighted mean of a number of foreign currencies as a ratio of price deflator. Therefore, the econometric model is estimated as follows:

$$
\operatorname{LnFDI}_{t}=\alpha+\beta_{2} \operatorname{LnMSZ}_{t}+\beta_{3} \operatorname{LnTO}_{t}+\beta_{3} \operatorname{LnRER}_{t}+\varepsilon_{t}
$$

where LnFDI is for natural logarithm of inflow of foreign direct investment, LnMSZ is market size , LnTO is trade openness, and LnRER is the real exchange rate, $\operatorname{Ln} \beta_{1}=\alpha$ and $\varepsilon_{t}$ is for error term.

\subsection{Autoregressive Distributed Lag (ARDL) Model}

In this study, we use ARDL approach introduced by Pesaran, Shin, and Smith (2001) with an objective to investigate the long and short-run relationships among the variables of interest. This ARDL cointegration method is better than the traditional cointegration techniques suggested by Johansen (1988) and Johansen and Juselius (1990), as it uses a single equation. Notwithstanding of its outperformance, it is noteworthy to mention that ARDL has several advantages over other time series models. Its advantages include: (1) ARDL is easily applicable; it means all the variables under the study are not required to be integrated at same order. It uses the variables regardless of whether they are at purely (0), or purely (1) or fractionally integrated (i.e., a mixture of both); nevertheless, the integration should not exceed one. In addition, pre-testing of variables, such as unit root test is not so important. (2) It circumvents too many specifications, like the number of endogenous and exogenous variables to be included, the order of vector autoregression (VAR), the dealing of deterministic elements and an optimal number of lags to be applied (Bhasin \& Gupta, 2017b). In the contrary, it enables variables to show different optimal lags; (3) it estimates all together parameters of both short and long-run estimates along with variance-covariance matrix, subsequently, it provides reliable and consistent results, which alternate cointegration methods cannot produce;(4) it applies a single reduced-form equation which exhibits robust to misspecification of the full equation and (5) it is more efficient in case of small or infinite sample size (Arize, 2017). More specifically, ARDL model offers reliable results with 30 up to 80 observations(Bhasin \& Gupta, 2017b). The model is required to satisfy a set of critical points set by initially by Narayan (2005). The ARDL method used in this study is expressed as follows:

$$
\begin{aligned}
& \Delta\left[\operatorname{Ln}(F D I)_{t}\right]=\beta_{0}+\sum_{i=1}^{p} \phi_{i} \Delta \operatorname{Ln}(F D I)_{t-i}+\sum_{i=0}^{p} \theta_{i} \Delta \operatorname{Ln}(M S)_{t-i}+\sum_{i=0}^{p} \lambda_{i} \Delta \operatorname{Ln}(T O)_{t-i} \\
& +\sum_{i=0}^{p} \varphi_{i} \Delta \operatorname{Ln}(R E R)_{t-i}+\beta_{1} \operatorname{Ln}(F D I)_{t-1}+\beta_{2} \operatorname{Ln}(M S)_{t-1}+\beta_{3} \operatorname{Ln}(T O)_{t-1}+\beta_{3} \operatorname{Ln}(R E R)_{t-1}+\varepsilon_{t}
\end{aligned}
$$

\subsection{Unit Root Tests}

Econometric models of time series data require that the stationarity is tested as a prerequisite for running the data. For this purpose, we use Augmented Dickey-Fuller (ADF) and Phillips-Perron (PP) tests to check that the integration of all variables under the study are not I (2) because F statistic obtained from the variables integrated at I (2) is not easy to be interpreted in a meaningful way. In addition, if data is not stationary, a problem of spurious correlation arises, and the econometric model becomes invalid because inferential estimates obtained from are bias and inconsistent and results in misleading conclusions.

\subsection{Cointegration Analysis for ARDL}

This study applies ARDL approach developed by Pesaran et al. (2001) to estimate empirically long and short-run relationships among the selected variables: market size, trade openness, real exchange rates, and foreign direct investment inflows. The ARDL cointegration method is used as a vector autoregressive (VAR) estimator of order $p$ in $Y_{t}$, where $Y_{t}$ represents a column vector that consists of four variables: $Y_{t}=\left(F I_{t} M_{t} R_{t} R_{t} T_{t}\right)$. Bhasin and Gupta (2017b) underlined four important steps to be followed when estimating long and short-run parameters of ARDL model after established the consistency of ARDL model using a unit root as pre-testing. Firstly, one requires determining a system of unrestricted error correction estimators (UECM) which consists of a system of equations using each variable as regressand or predictor. As a result, separate equations are formed and then interpreted easily. We follow Belloumi (2014) error correction model and is expressed as follows:

$$
\begin{aligned}
& D\left(\operatorname{LnFDI}_{t}\right) ! \beta_{01} ! \beta_{11}\left(\operatorname{LnFDI}_{t: 1}\right) ! \beta_{21}\left(\operatorname{LnMS}_{t: 1}\right) ! \beta_{31}\left(\operatorname{LnTO}_{t: 1}\right) ! \beta_{41}\left(\operatorname{LnRER}_{t: 1}\right) ! !_{t: 1}^{p} \alpha_{1 i} D\left(\operatorname{LnFDI}_{t ! 1}\right) ! \\
& !_{t: 1}^{p} \alpha_{2 i} D\left(\text { LnMS }_{t ! 1}\right) ! !_{t ! 1}^{p} \alpha_{3 i} D\left(\text { LnTO }_{t ! 1}\right) ! !_{t ! 1}^{p} \alpha_{4 i} D\left(\text { LnRER }_{t ! 1}\right) ! !_{t}+\varepsilon_{t}
\end{aligned}
$$




$$
\begin{aligned}
& D\left(\operatorname{LnMS}_{t}\right) ! \beta_{02} ! \beta_{12}\left(\operatorname{LnFDI}_{t ! 1}\right) ! \beta_{22}\left(\operatorname{LnMS}_{t ! 1}\right) ! \beta_{32}\left(\operatorname{LnTO}_{t ! 1}\right) ! \beta_{42}\left(\operatorname{LnRER}_{t ! 1}\right) !_{t ! 1}^{p} \alpha_{2 i} D\left(\operatorname{LnFDI}_{t ! 1}\right) ! \\
& !_{t: 1}^{p} \alpha_{2 i} D\left(\operatorname{LnMS}_{t ! 1}\right) ! !_{t ! 1}^{p} \alpha_{3 i} D\left(\operatorname{LnTO}_{t ! 1}\right) ! !_{t: 1}^{p} \alpha_{4 i} D\left(\operatorname{LnRER}_{t ! 1}\right) ! !_{2 t}+\varepsilon_{t}
\end{aligned}
$$

where $\mathrm{FDI}_{\mathrm{t}}$ is foreign direct investment, $\mathrm{MS}_{\mathrm{t}}$ is market size, $\mathrm{RER}_{\mathrm{t}}$ is real exchange rate $\mathrm{TO}_{\mathrm{t}}$ is trade openness, $\beta^{\prime} s$ are the long run coefficients, $\alpha^{\prime} s$ are short-run estimates, $\mathrm{L}$ is natural logarithms, $\mathrm{D}$ is the operator of the first differenced, and $\varepsilon^{\prime} s$ are the error terms.

We estimate four equations (3 and 4) using standard ordinary least square and then test their cointegration by using Wald test (F-statistic) in which the null hypothesis of cointegration states that there is of no cointegration: i.e., $\mathrm{H}_{0}: \beta_{1 i}=\beta_{2 i}=\beta_{3 i}=\beta_{4 i}=0$, while the alternative hypothesis states that there is cointegration, implying that there is a long run relationship between lagged variables: $\mathrm{H}_{1}: \beta_{1 i} \neq \beta_{2 i} \neq \beta_{3 i} \neq \beta_{4} i \neq 0$. The decision about presence of the long-run relationships between the variables are based on the lower and upper critical bounds set out by Pesaran et al. (2001) For instance, when the computed F-statistic is greater than the upper bound; the null hypothesis is rejected which means cointegration (long-run relationship) exists, while if it is less than the lower bound; the null hypothesis is not rejected, which means cointegration does not exist, and an inconclusive decision is drawn if it lies between the upper and lower bounds.

Secondly, when the presence of long-run relationships between variables is established, we then conduct diagnostic tests of serial correlation, heteroscedasticity, and instability to ensure whether the ARDL model is free from these econometric issues. The stability of long-run coefficients is essential as forming short run error correction model. It is used to identify short-run dynamics and cumulative sum of recursive residuals (CUSUM) and cumulative sum of squares residuals (CUSUMSQ) developed by Brown, Durbin, and Evans (1975) are used to test the stability of the model. Moreover, we estimate coefficients of long-run ARDL ( $p, q, r)$ model and the corresponding ARDL error correction model for the short-run coefficients if the ARDL model passes all diagnostic tests. The following equation determines the long run relationship between variables:

$$
\Delta\left[\operatorname{Ln}(F D I)_{t}\right]=\beta_{0}+\beta_{1} \operatorname{Ln}(F D I)_{t-1}+\beta_{2} \operatorname{Ln}(M S)_{t-1}+\beta_{3} \operatorname{Ln}(T O)_{t-1}+\beta_{4} \operatorname{Ln}(R E R)_{t-1}+\varepsilon_{t}
$$

where LnFDI is a dependent variable and independent variables are denoted as $\mathrm{X}(1), \mathrm{X}(2)$ and $\mathrm{X}(3), \beta_{0}$ is the constant term and $\mathcal{E}_{t}$ is a white noise error term. Finally, we estimate ECM which provides the speed of correction or adjustment of the respective model back to the long run equilibrium subsequent a short run shock, and short-run dynamics is specified as follows:

$$
\Delta \operatorname{Ln}(F D I)_{t}=\alpha_{2}+\sum_{i=1}^{p} \phi_{2 i} \Delta \operatorname{Ln}(M S)_{t-i}+\sum_{i=0}^{p} \theta_{2 i} \Delta \operatorname{Ln}(T O)_{t-i}+\sum_{i=0}^{p} \lambda_{2 i} \Delta \operatorname{Ln}(R E R)_{t-i}+\psi E C M_{t-1}+\vartheta_{t}
$$

where $\mathrm{ECM}_{\mathrm{t}-1}$ is the error correction term which was obtained from the long-term estimated parameters in Eq. (7). In addition, the error correction term should be significant and negatively correlated with the dependent variable.

This step involves the selection of optimum lag orders for considering ARDL model (p, q, r, s) within four variables structure. Pesaran and Shin (1999) have shown that the valid asymptotic inferences on short- and long-run parameters made under least squares estimates of an ARDL model (Narayan \& Smyth, 2004). As the data is annual, we use the Akaike information criteria (AIC) to determine minimum numbers of lags used in the model.

\subsection{Granger Causality Test}

The existence of cointegration between variables indicates that there is causality in at least one direction. The Granger causality test proposed by Granger $(1969,1988)$ is used to check short-run causality: i.e., lagged differenced independent variables, such as foreign direct investment, market size, trade openness and real exchange rate for South Africa and long-run causality of lagged error correction model (ECM) as well. Therefore, we to test the direction of causality between the variables following vector error correction model (VECM) given below:

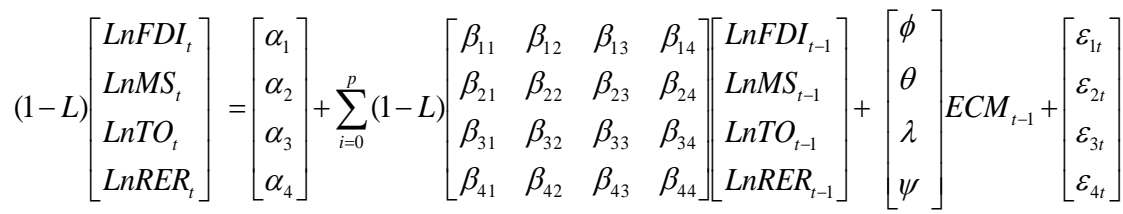

where $(1-\mathrm{L})$ indicates the difference operator. $\mathrm{ECM}_{\mathrm{t}-1}$ represents the lagged residuals obtained from long-run 
relationship model whereas $\varepsilon_{l t}, \varepsilon_{2}, \varepsilon_{3 t}$, and $\varepsilon_{4 t}$ disturbance terms are assumed to be normally distributed with mean zero and finite covariance matrix. The statistical significance in t-statistic of a coefficient of lagged error correction term $\left(\mathrm{ECT}_{\mathrm{t}-1}\right)$ indicates the long run causality while the short run causality is shown by statistical significance of F-statistic in first differences of the variables.

\section{Empirical Results and Discussion}

Table 1 presents the descriptive statistics and correlation matrix in which all the variables are normally distributed as indicated by the statistical test of Jarque-Bera. The domestic market size (MSZ) showed the highest mean score of all the series, while the mean average of foreign direct investment (LnFDI) was the lowest. The correlation analysis revealed that domestic market size and trade openness were positively correlated with foreign direct investment whereas the real exchange rate had a negative relationship with the foreign direct investment. However, the results were in line with our research expectations. In addition, the links of the series were high except the trade openness which showed moderate association with the foreign direct investment.

Table 1. Descriptive statistics and correlation matrix

\begin{tabular}{lcccc}
\hline Variables & LnFDI & LnTOP & LnMSZ & LnRER \\
\hline Mean & 3.039 & 3.970 & 4.960 & 4.681 \\
Median & 3.046 & 3.994 & 5.051 & 4.645 \\
Maximum & 3.136 & 4.289 & 5.777 & 5.128 \\
Minimum & 2.835 & 3.624 & 4.081 & 4.270 \\
Std. Dev. & 0.082 & 0.161 & 0.507 & 0.247 \\
Skewness & -0.743 & -0.342 & -0.245 & 0.221 \\
Kurtosis & 2.693 & 2.513 & 1.882 & 1.940 \\
Jarque-Bera & 2.877 & 0.880 & 1.863 & 0.439 \\
Probability & 0.237 & 0.644 & 0.394 & \\
LnFDI & 1.000 & & & 1.000 \\
LnTOP & 0.274 & 1.000 & 1.000 & \\
LnMSZ & 0.777 & 0.221 & -0.825 & \\
LnRER & -0.818 & -0.424 & & \\
\hline
\end{tabular}

\subsection{Unit Root Test Results}

Table 2 reports the results of unit root analysis. We checked the unit root issue and integration order of the series, albeit, ARDL model does not require pre-testing. However, it is crucial empirically to carry out this test to ascertain that no variable is integrated at I(2) and does not have unit root problem as ARDL model can be applied when the variables are integrated at $\mathrm{I}(0)$ or $\mathrm{I}(1)$ or mixed. If any variable is obtained to be stationary at $\mathrm{I}(2)$ or more, inferences obtained from this model are bias and unreliable leading to long-run cointegration inconsistent. We used conventional Augmented Dickey-Fuller (ADF), and Phillips-Perron (PP) tests with constant and constant with time trend to confirm that all the series are free from the unit root problems and integration order of two or more. The results revealed that the series were non-stationary at levels under intercept. Nonetheless, all the variables were stationary in the first difference under both intercept and intercept and trend. In addition, no single variable was integrated at I(2) or more.

Table 2. Results of unit root analysis

\begin{tabular}{|c|c|c|c|c|}
\hline \multirow[t]{2}{*}{ Variables } & \multicolumn{2}{|c|}{ Augmented Dickey-Fuller (ADF)Test } & \multicolumn{2}{|c|}{ Phillips-Perron (PP) Test } \\
\hline & Intercept & Intercept and trend & Intercept & Intercept and trend \\
\hline \multicolumn{5}{|l|}{ Level } \\
\hline LnFDI $_{t}$ & -1.739 & $-3.977^{* * *}$ & -2.384 & $-3.805^{* *}$ \\
\hline $\mathrm{LnMS}_{\mathrm{t}}$ & -0.160 & $-5.890^{* * * *}$ & -1.062 & $-5.889^{* * *}$ \\
\hline $\operatorname{LnTO}_{t}$ & -1.724 & -2.079 & -1.647 & -1.969 \\
\hline LnRER $_{t}$ & -0.925 & $-3.399^{*}$ & -0.699 & -2.615 \\
\hline \multicolumn{5}{|c|}{ In first difference } \\
\hline$\Delta \mathrm{LnFDI}_{\mathrm{t}}$ & $-6.940^{* * *}$ & $-6.800^{* * * *}$ & $-16.974^{* * *}$ & $-16.357^{* * *}$ \\
\hline$\Delta L n \mathrm{MS}_{\mathrm{t}}$ & $-6.851^{* * *}$ & $-6.746^{* * *}$ & $-11.667^{* * *}$ & $-11.481^{* * *}$ \\
\hline$\Delta \mathrm{LnTO}_{\mathrm{t}}$ & $-4.661^{* * *}$ & $-4.750^{* * *}$ & $-5.926^{* * *}$ & $-7.900^{* * *}$ \\
\hline$\Delta$ LnRER $_{\mathrm{t}}$ & $-4.529^{* * *}$ & $-4.441^{* * *}$ & $-4.862^{* * * *}$ & $-4.720^{* * * *}$ \\
\hline
\end{tabular}

Note. $* * * * *$ and $*$ represent significance at $1 \%, 5 \%$ and $10 \%$ respectively. 


\subsection{Cointegration Analysis}

It is essential to select the optimal lag length before cointegration analysis since the estimation of ARDL model is sensitive to the selection of lag length. If an appropriate lag length is not chosen, it may provide biased results which conclude wrong decision to be drawn (Shahbaz, 2012). In that sense, we employed an unrestricted error correction (UECM) model to determine the maximum lag length by applying the Akaike Information Criterion (AIC) and Schwarz Bayesian Criterion (SBC). Therefore, we chose the lag length of 3 for the ARDL technique and results are shown in the table below.

Table 3. Lag order selection

\begin{tabular}{lcl}
\hline Number of lags & AIC* & BIC \\
\hline 1 & 3.165 & 3.407 \\
2 & 3.168 & 3.555 \\
3 & $3.079^{*}$ & 3.853 \\
4 & 3.103 & 3.926 \\
\hline
\end{tabular}

Note. AIC: Akaike information criterion and SC: Schwarz information criterion.

Additionally, lag 3 was found as applicable to the ARDL technique, we then proceeded the long run cointegration analysis and the confirmation of cointegration was based on critical bounds set by Narayan (2005) rather than Pesaran et al. (2001). The critical bounds of Narayan (2005) are appropriate for this study due to its small sample size $(\mathrm{T}=30)$. Thus, the results of computed F-statistic of each unrestricted error correction (UECM) regression in which variable is considered as a dependent variable are presented in Table 4. Moreover, the findings show the existence of cointegration that confirms the long run relationship between foreign direct investment inflows, trade openness, market size and real exchange rates in South Africa. Interestingly, the equation (1) for $\mathrm{F}_{\mathrm{FDI}}\left(\mathrm{MSZ}\right.$ TO RER) $=6.194$ and equation (2) for $\mathrm{F}_{\mathrm{MSZ}}(\mathrm{FDI}$ TO RER)= 5.936 revealed that that long run relationships exist amongst the variables when FDI and MSZ were taken the dependent variables as the computed F-values (6.194 and 5.936) are higher than the upper critical bounds of Narayan (2005) respectively. To that effect, they suggest the null hypothesis which state no cointegration among the variables in equations (1) and (2) are rejected.

Table 4. Bounds cointegration test

\begin{tabular}{lccc}
\hline Dependent variable & AIC lags & Computed F-statistic & Decision \\
\hline $\mathrm{F}_{\mathrm{FDI}}($ MSZ TO RER) & 3 & 6.194 & Cointegration \\
$\mathrm{F}_{\mathrm{MSZ}}$ (FDI TO RER) & 1 & 5.936 & Cointegration \\
$\mathrm{F}_{\mathrm{TO}}$ (MSZ FDI RER) & 4 & 3.282 & No cointegration \\
$\mathrm{F}_{\text {RER }}$ (MSZ TO FDI) & 2 & 0.820 & No cointegration \\
\hline & & \multicolumn{2}{c}{ Critical value(T=30) } \\
\hline Significance level & & Lower Bounds & Upper Bounds \\
\hline $1 \%$ & & 4.29 & 5.61 \\
$5 \%$ & & 3.23 & 4.35 \\
$10 \%$ & & 2.72 & 3.77 \\
\hline
\end{tabular}

Note. Critical values for bounds test are from Narayan (2004) with restricted intercept and no trend.

Table 4 presents the estimates for the ARDL models and results of their diagnostic checks. Since the consistency of ARDL model requires being free all econometric problems which render its parameter estimates bias and inconsistent. To that effect, we conducted all necessary diagnostic checks. In doing so, the results revealed that both ARDL estimators are free from all econometric issues. For instance, firstly, both models of ARDL techniques do not suffer serial correlation as Breusch-Godfrey LM test showed that presence of serial correlation was rejected, suggesting that the null hypothesis which states that there is no serial correlation was failed to reject, secondly they models are also free from heteroscedasticity issue as the autoregressive conditional heteroscedasticity (ARCH) showed that the residuals were homoscedastic and regressors were independent. Thirdly, the Jacque-Bera normality test indicated that the residuals were normally distributed. Finally, Ramsey check indicated that the model was well specified as well. As the ARDL model satisfied all requirement mentioned above, therefore, we proceeded to analyze short and long-run effects. 
Table 5. Selected models: ARDL (3, 3, 3, 3) and ARDL $(1,0,2,3)$

\begin{tabular}{|c|c|c|c|c|c|c|c|}
\hline \multirow[b]{2}{*}{ Variable } & \multicolumn{3}{|c|}{ Dependent: LnFDI } & \multicolumn{4}{|c|}{ Dependent: LnMSZ } \\
\hline & Coefficient & T-ratio & Prob. & Variable & Coefficient & T-ratio & Prob. \\
\hline LnFDI(-1) & -0.160 & -0.710 & 0.493 & $\operatorname{MSZ}(-1)$ & -0.019 & -0.096 & 0.925 \\
\hline $\operatorname{LnFDI}(-2)$ & -0.729 & -2.538 & 0.028 & FDI & 10.445 & 1.394 & 0.181 \\
\hline $\operatorname{LnFDI}(-3)$ & -0.826 & -2.748 & 0.019 & TOP & -0.441 & -0.284 & 0.780 \\
\hline LnMSZ & 0.014 & 2.111 & 0.059 & TOP(-1) & -2.381 & -1.172 & 0.257 \\
\hline $\operatorname{LnMSZ(-1)}$ & 0.014 & 1.980 & 0.073 & TOP(-2) & 4.201 & 2.622 & 0.018 \\
\hline LnMSZ(-2) & -0.004 & -0.597 & 0.563 & RER & 0.066 & 0.086 & 0.932 \\
\hline $\operatorname{LnMSZ(-3)}$ & 0.018 & 2.115 & 0.058 & $\operatorname{RER}(-1)$ & -2.485 & -2.270 & 0.037 \\
\hline LnTOP & -0.086 & -1.280 & 0.227 & $\operatorname{RER}(-2)$ & 2.801 & 2.593 & 0.019 \\
\hline $\operatorname{LnTOP}(-1)$ & 0.160 & 1.751 & 0.108 & $\operatorname{RER}(-3)$ & -2.335 & -3.487 & 0.003 \\
\hline $\operatorname{LnTOP}(-2)$ & -0.242 & -2.632 & 0.023 & Constant & 101.135 & 0.484 & 0.634 \\
\hline $\operatorname{LnTOP}(-3)$ & 0.079 & 1.415 & 0.185 & $\mathrm{R}^{2}$ & 0.853 & & \\
\hline LnRER & 0.030 & 1.017 & 0.331 & & & & \\
\hline $\operatorname{LnRER}(-1)$ & -0.012 & -0.304 & 0.767 & & & & \\
\hline $\operatorname{LnRER}(-2)$ & -0.114 & -2.627 & 0.024 & & & & \\
\hline $\operatorname{LnRER}(-3)$ & 0.031 & 1.113 & 0.290 & & & & \\
\hline Constant & 62.258 & 4.150 & 0.002 & & & & \\
\hline R-squared & 0.875 & & & & & & \\
\hline Adjusted- $\mathrm{R}^{2}$ & 0.703 & & & & & & \\
\hline \multicolumn{8}{|l|}{ Diagnostics } \\
\hline Serial correlation & \multicolumn{3}{|c|}{$0.124(0.940)$} & & \multicolumn{3}{|c|}{$0.144(0.931)$} \\
\hline Ramsey RESET & \multicolumn{3}{|c|}{$4.150(0.528)$} & & \multicolumn{3}{|c|}{$1.884(0.189)$} \\
\hline J-B Normality test & \multicolumn{3}{|c|}{$4.159(0.125)$} & & \multicolumn{3}{|c|}{$3.704(0.831)$} \\
\hline Breusch-Godfrey LM test & \multicolumn{3}{|c|}{$9.032(0.876)$} & & \multicolumn{3}{|c|}{$9.182(0.421)$} \\
\hline
\end{tabular}

\subsection{Long Run Dynamic ARDL Estimators}

Once cointegration is established, the following task is to investigate the long run relationships between the variables: foreign direct investment, market size, trade openness and real exchange rate. The findings documented that trade openness and market size have statistically significant and positive impacts on foreign direct investment at $1 \%$ significant level, whereas real exchange rate has signed an adverse effect in model 1 when the FDI serves as a dependent. However, in model 2, only the real exchange rate is high and negative when market size is randomized (as a dependent). The results imply $1 \%$ rise in trade openness increases foreign direct investment inflows in South Africa by 3\% in the long run when keeping other factors same. These findings are attributed to the increases in physical capital as well as a transfer of technology. These results are with a line in the existing literature (Belloumi, 2014).

An increase in foreign direct investment is inversely linked with real exchange rate depreciation implying that real exchange rate declines foreign direct investment through depreciation of real exchange rate of South Africa, all others keeping constant. It suggests a rise of $1 \%$ in the real exchange rate would lead to $2.4 \%$ decrease in the foreign direct investment. Conversely, the appreciation of real exchange rate rises foreign direct investment inflows in South Africa, indicating as the real exchange rate strengthens, it strongly attracts the foreign direct investment in the long run.

Moreover, the market size has statistically significant and positive effect on foreign direct investment in the long run at a significant level of $1 \%$. It implies an increase of $1 \%$ in market size would cause foreign direct investment to grow up by $1.6 \%$ appropriately and the result is concordance with the previous studies (Elshamy, 2017). Multinational firms underline the importance of large domestic markets as they are crucial for products to be sold locally rather than export. Therefore, South Africa should make sure the foreign direct investment inflows being used efficiently, particularly these funds should be invested in sectors which develop economies. Since foreign direct investment inflows depend upon the consideration in which South African government gives the market size.

These findings offer support to any policy change that may attract foreign direct investment. A policy adopted by the South African government which encourages foreign investors to invest domestic firms may lead to improving export volume and fund flows. In that sense, these fund inflows create new jobs, improve technology 
transfer, and increase foreign exchange profits. As a result, the economic growth of South Africa is boosted.

Table 6. Long run coefficients

\begin{tabular}{lcccc}
\hline Variables & \multicolumn{2}{c}{ Mode1: LnFDI (Dependent) } & \multicolumn{2}{c}{ Mode2: LnMSZ (Dependent) } \\
\cline { 2 - 5 } & Coefficient & T-ratio & Coefficient & T-ratio \\
\hline LnMSZ & 0.016 & {$[4.281]^{* * *}$} & - & - \\
LnTOP & 0.033 & {$[2.732]^{* * *}$} & 1.352 & {$[1.377]$} \\
LnRER & -0.024 & {$[-2.677]^{* * *}$} & -1.916 & {$[-4.101]^{* * *}$} \\
LnFDI & - & - & 10.249 & {$[1.428]$} \\
\hline
\end{tabular}

Note. $* * *$ represents significant level of $1 \%$.

\subsection{Short Run Error Correction Models}

Table 7 reports empirical results of short-run models applying error correction method (ECM). There are two models: model 1 represents when the FDI serves as dependent variable and model 2 stands for when MSZ is dependent. The results show a positive effect of market size on foreign direct investment, and it is statistically significant at 5\% level. A rise in market size is positively correlated with foreign direct investment, indicating market size is the only dominant factor in the short run. However, model 2, no single variable is significant. ECM must be significant and negative within between -1 and 0 as a prerequisite condition which requires being satisfied. Moreover, ECM ratifies the evidence of long-run adjustment to equilibrium position or the speed of adjustment of the whole system will converge to the mean position. With that respect, the lagged ECM is statistically significant and negative with speed of $14.7 \%$ in model 1 and $18 \%$ in model2, indicating that change from equilibrium level of FDI is corrected by $14.7 \%$ per year, implying overall correction takes seven years appropriately to get back to equilibrium.

Table 7. Short run results

\begin{tabular}{lcccc}
\hline \multirow{2}{*}{ Variable } & \multicolumn{2}{c}{ Model 1 } & \multicolumn{2}{c}{ Model 2 } \\
& \multicolumn{2}{c}{ Dependent variable[ D(FDI)] } & Dependent variable[ D(MSZ)] \\
\cline { 2 - 5 } & Coefficient & T-ratio & Coefficient & T-ratio \\
\hline D(LnFDI) & - & - & 11.392 & {$[2.296]^{* *}$} \\
D(LnMSZ) & 0.014 & {$[2.775]^{* *}$} & - & - \\
D(LnTOP) & -0.086 & {$[-1.748]$} & -0.520 & {$[-0.383]$} \\
D(LnRER) & 0.030 & {$[1.200]$} & 0.045 & {$[0.064]$} \\
ECT(-1) & -0.147 & {$[-5.615]^{* * *}$} & -0.18 & {$[-5.578]^{* * *}$} \\
Constant & 62.258 & {$[5.616]^{* * *}$} & 100.866 & {$[5.765]^{* * *}$} \\
Diagnostics & & & & 0.325 \\
R-squared & & 0.873 & & 0.200 \\
Adjusted-R & & 0.648 & & $2.526(0.07)$ \\
F-statistics & & $3.873(0.022)$ & & 2.526 \\
Durbin-Watson & & 1.884 & & $0.093(0.954)$ \\
J-B normality test & & $3.463(0.177)$ & & $6.318(0.043)$ \\
Breusch-Godfrey LM test & & $8.336(0.016)$ & & $0.107(0.7434)$ \\
ARCH LM test & & $0.227(0.633)$ & & $0.000(0.987)$ \\
Ramsey RESET & & $2.759(1.182)$ & & \\
\hline
\end{tabular}

\subsection{Granger causality Approach}

When the existence of cointegration relationship is confirmed, Granger causality among variables requires to be tested (Engle \& Granger, 1987). Granger (1988) argued that the standard VAR model cannot identify short and long-run causality and included lagged error-correction term to short-run equations to capture the long-run causality while short-run causality is derived from short-run equations. To that effect, we use Granger causality test to both short and long-run causality following the empirical model developed by Bhasin and Gupta (2017b) and their results are shown in Table 8. 
Table 8. Granger causality analysis

\begin{tabular}{lcccc}
\hline \multirow{2}{*}{ Direction of causality } & \multicolumn{4}{c}{ Type of Granger Causality Test } \\
\cline { 2 - 5 } & \multicolumn{3}{c}{ Short run } & \multicolumn{2}{c}{ Long run(ECM $\left.\mathrm{EC}_{\mathrm{t}-1}\right)$} \\
\cline { 2 - 5 } & F-statistics & Prob-value & F-statistics & Prob-value \\
\hline$D(\ln F D I) \Rightarrow D(\ln R E R)$ & 5.919 & {$[0.023]^{* * *}$} & 7.479 & {$[0.012]^{* * *}$} \\
$D(\ln M S Z) \Rightarrow D(\ln T O P)$ & 3.480 & {$[0.074]^{* *}$} & 0.422 & {$[0.523]$} \\
\hline
\end{tabular}

The results reveal that the Granger causality between foreign direct investments to the real exchange rate is statistically significant at $1 \%$ level of significance, indicating the causality is unidirectional running from foreign direct investment to real exchange rate in short and long run. Furthermore, the F-statistics on the relationship between market size (MSZ) and trade openness show statistical significance at the $1 \%$ significant level. The Granger causality between foreign direct investment and real exchange rate is unidirectional running from market size to trade openness in a short run.

Tests, such as cumulative sum of recursive residuals (CUSUM) and CUSUM of square (CUSUMSQ) are used to check stability. In a time series, the model that is improperly specified produces biased coefficients which result in reducing the explaining power of the empirical analysis(Hanson, 2002). These stability tests are used to check the constancy of the parameter estimates of ARDL model (Shahbaz, 2013). Brown et al. (1975) stated that the residuals are insensitive to small or gradual changes in parameter estimates. Any changes in coefficients are detected in recursive residuals by hypothesizing the coefficients of ARDL estimator are constant over time. The stability of coefficients depends upon the recursive residuals. For example, if the parameter estimates are constant, it implies that the recursive residuals tend to be zero (Shahbaz, 2013). The results showed that the plots do not cross the critical value, as a result, the ARDL model is said to be stable as the lines did not traverse the critical lines. Therefore, the model is appropriate for applying policy for decision making in South Africa.
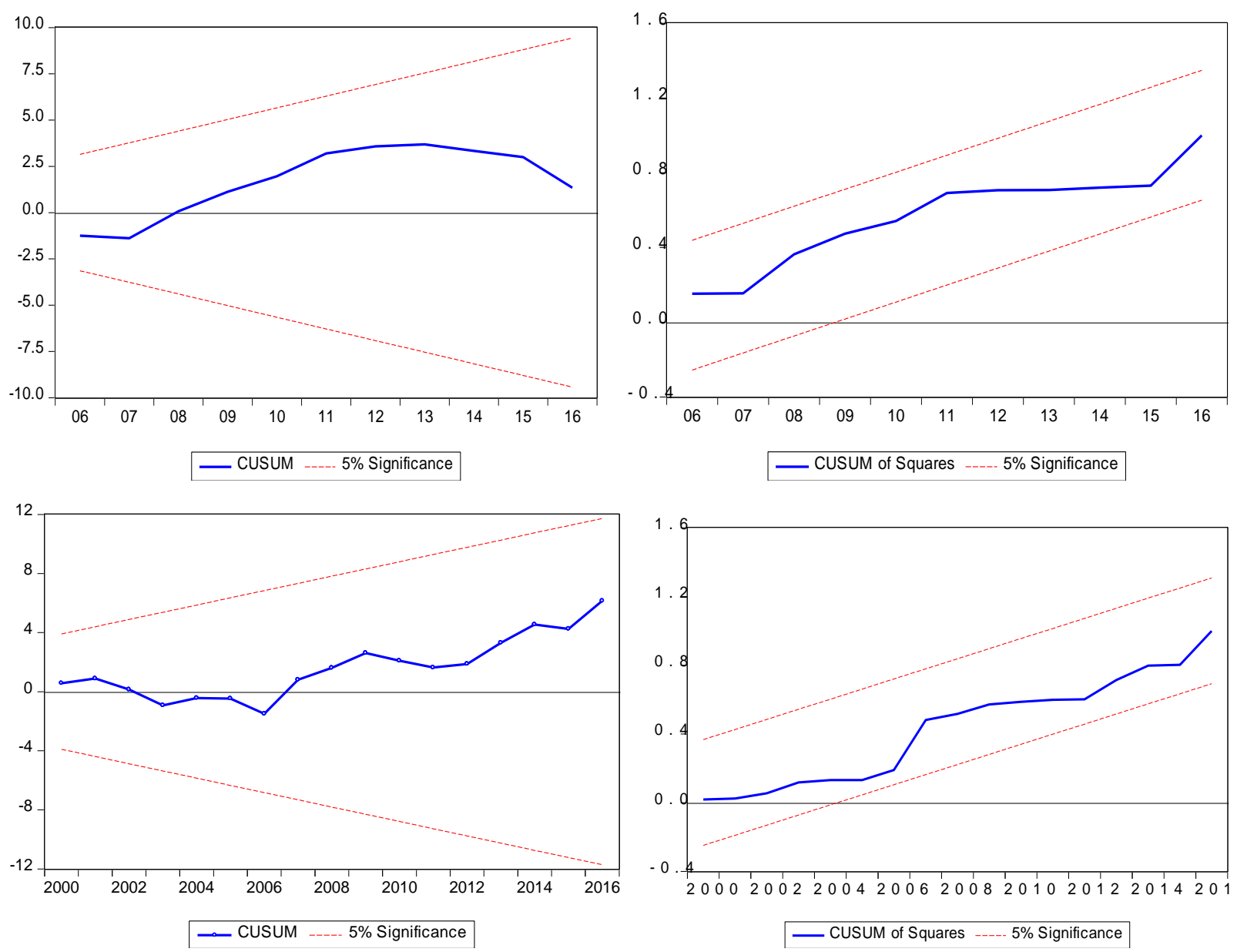

Figure 1. Plots of as cumulative sum of recursive residuals (CUSUM) and CUSUM of square (CUSUMSQ) Note. The straight lines represent critical bounds at $5 \%$ significance level. 


\section{Conclusion and Policy Implication}

The aim of this study is to examine the effect of real exchange rate on foreign direct investment in South Africa. The study investigates the dynamic causal relationship between real exchange rate, foreign direct investment, trade openness, and market size for the period of 1987-2016. It applies an ARDL approach to cointegration to test whether the long run relationships between the series exist and Granger causality to check the direction of causality between the variables. The results show that real exchange rate and domestic market size establish long-run cointegration, implying both real exchange rate, domestic market size promote the foreign direct investment. The findings documented that trade openness and market size have statistically significant and positive impacts on foreign direct investment at $1 \%$ significant level, whereas real exchange rate has signed a negative effect when the FDI serves as a dependent. However, only the real exchange rate is negative and strong when market size is randomized (as a dependent). The results imply $1 \%$ rise in trade openness increases foreign direct investment inflows in South Africa by $3 \%$ in the long run when keeping other factors same. These findings are attributed to the increases in physical capital as well as the transfer of technology.

Additionally, in a short run, the results show positive and significant effects of market size on foreign direct investment at 5\% significant level. A rise in market size is positively correlated with foreign direct investment, indicating market size is the only dominant factor in the short run. The lagged ECM is statistically significant and negative with speed of $14.7 \%$, indicating that change from equilibrium level of FDI is corrected by $14.7 \%$ per year, implying overall correction takes seven years appropriately to get back to equilibrium. Furthermore, the Granger causality reveals the unidirectional causality running from foreign direct investment to the real exchange rate in short and long run. And the Granger causality between foreign direct investment and the real exchange rate is statistically significant at the $1 \%$ significant level and is unidirectional running from market size to trade openness in a short run.

These findings offer insights to policy-makers about an approach to attract foreign direct investment. It suggests a policy that monitors the real exchange rate to avoid exchange rate instability. Stable real exchange rate encourages foreign direct investment.

\section{References}

Arize, A. C. (2017). A convenient method for the estimation of ARDL parameters and test statistics: USA trade balance and real effective exchange rate relation. International Review of Economics \& Finance, 50, 75-84. https://doi.org/10.1016/j.iref.2017.03.024

Belloumi, M. (2014). The relationship between trade, FDI and economic growth in Tunisia: An application of the autoregressive distributed lag model. Economic Systems, 38(2), 269-287. https://doi.org/10.1016/j.ecosys.2013.09.002

Bhasin, N., \& Gupta, A. (2017a). Macroeconomic impact of FDI inflows: An ARDL approach for the case of India. Transnational Corporations Review, 9(3), 150-168. https://doi.org/10.1080/19186444.2017.1362860

Bhasin, N., \& Gupta, A. (2017b). Macroeconomic impact of FDI inflows: An ARDL approach for the case of India. Transnational Corporations Review, 1-19.

Brown, R. L., Durbin, J., \& Evans, J. M. (1975). Techniques for testing the constancy of regression relationships over time. Journal of the Royal Statistical Society. Series B (Methodological), 149-192.

Cuyvers, L., Soeng, R., Plasmans, J., \& Van Den Bulcke, D. (2011). Determinants of foreign direct investment in Cambodia. Journal of Asian Economics, 22(3), 222-234. https://doi.org/10.1016/j.asieco.2011.02.002

Dunning, J. H. (1991). The eclectic paradigm of international production. The Nature of the Transnational Firm, 121.

Dunning, J. H., \& Lundan, S. M. (2008). Multinational enterprises and the global economy: Edward Elgar Publishing.

Elshamy, H. (2017). The economic determinants of Chinese foreign direct investment in Egypt, China and Africa (pp. 189-198). Springer.

Engle, R. F., \& Granger, C. W. (1987). Co-integration and error correction: Representation, estimation, and testing. Econometrica: Journal of the Econometric Society, 251-276. https://doi.org/10.2307/1913236

Granger, C. W. (1969). Investigating causal relations by econometric models and cross-spectral methods. Econometrica: Journal of the Econometric Society, 424-438. https://doi.org/10.2307/1912791

Granger, C. W. (1988). Causality, cointegration, and control. Journal of Economic Dynamics and Control, 
12(2-3), 551-559. https://doi.org/10.1016/0165-1889(88)90055-3

Gupta, P., \& Singh, A. (2016). Causal nexus between foreign direct investment and economic growth: A study of BRICS nations using VECM and Granger causality test. Journal of Advances in Management Research, 13(2), 179-202. https://doi.org/10.1108/JAMR-04-2015-0028

Hanson, B. E. (2002). Tests for parameter instability in regressions with I(1) processes. Journal of Business \& Economic Statistics, 20(1), 45-59. https://doi.org/10.1198/073500102753410381

Iamsiraroj, S. (2016). The foreign direct investment-economic growth nexus. International Review of Economics \& Finance, 42, 116-133. https://doi.org/10.1016/j.iref.2015.10.044

Iqbal Chaudhry, N., Mehmood, A., \& Saqib Mehmood, M. (2013). Empirical relationship between foreign direct investment and economic growth: An ARDL co-integration approach for China. China Finance Review International, 3(1), 26-41. https://doi.org/10.1108/20441391311290767

Johansen, S. (1988). Statistical analysis of cointegration vectors. Journal of Economic Dynamics and Control, 12(2-3), 231-254. https://doi.org/10.1016/0165-1889(88)90041-3

Johansen, S., \& Juselius, K. (1990). Maximum likelihood estimation and inference on cointegration-with applications to the demand for money. Oxford Bulletin of Economics and statistics, 52(2), 169-210. https://doi.org/10.1111/j.1468-0084.1990.mp52002003.x

Kumar, S. (2013). Trends and patterns of FDI in India and China: A comparative study. International Journal of Education and Management Studies, 3(2), 309.

Liu, X., Wang, C., \& Wei, Y. (2001). Causal links between foreign direct investment and trade in China. China Economic Review, 12(2), 190-202. https://doi.org/10.1016/S1043-951X(01)00050-5

Narayan, P. K. (2005). The saving and investment nexus for China: Evidence from cointegration tests. Applied Economics, 37(17), 1979-1990. https://doi.org/10.1080/00036840500278103

Pesaran, M. H., Shin, Y., \& Smith, R. J. (2001). Bounds testing approaches to the analysis of level relationships. Journal of Applied Econometrics, 16(3), 289-326. https://doi.org/10.1002/jae.616

Seetanah, B., \& Rojid, S. (2011). The determinants of FDI in Mauritius: A dynamic time series investigation. African Journal of Economic and Management Studies, 2(1), 24-41. https://doi.org/10.1108/20400701111110759

Severiano, A. A. F. (2011). The determinants of FDI in Portugal: A sectorial approach.

Shahbaz, M. (2012). Does trade openness affect long run growth? Cointegration, causality and forecast error variance decomposition tests for Pakistan. Economic Modelling, 29(6), 2325-2339. https://doi.org/10.1016/j.econmod.2012.07.015

Shahbaz, M. (2013). Does financial instability increase environmental degradation? Fresh evidence from Pakistan. Economic Modelling, 33, 537-544. https://doi.org/10.1016/j.econmod.2013.04.035

Tang, C. F., \& Chua, S. Y. (2012). The savings-growth nexus for the Malaysian economy: A view through $\begin{array}{lllll}\text { rolling sub-samples. } & \text { Applied } & \text { Economics, } & \text { 44(32), }\end{array}$ https://doi.org/10.1080/00036846.2011.587784

Tang, C. F., Yip, C. Y., \& Ozturk, I. (2014). The determinants of foreign direct investment in Malaysia: A case for electrical and electronic industry. Economic Modelling, 43, 287-292. https://doi.org/10.1016/j.econmod.2014.08.017

Wong, H. T. (2017). Real exchange rate returns and real stock price returns. International Review of Economics and Finance, (49), 340-352. https://doi.org/10.1016/j.iref.2017.02.004

\section{Copyrights}

Copyright for this article is retained by the author(s), with first publication rights granted to the journal.

This is an open-access article distributed under the terms and conditions of the Creative Commons Attribution license (http://creativecommons.org/licenses/by/4.0/). 